\title{
Calibration of Design Fatigue Factors for Offshore Wind Turbine Support Structure based on Fatigue Test Database
}

\author{
Wangwen Zhao ${ }^{1}$, Wei-Ting Hsu ${ }^{2}$ \\ 1 Offshore Design Engineering Ltd., London, UK; wangwen.zhao@ode-ltd.co.uk \\ 2 Offshore Design Engineering Ltd., London, UK; wei-ting.hsu@ode-ltd.co.uk
}

\begin{abstract}
The concept of Design Fatigue Factors (DFFs) was introduced for providing desired level of safety in structural fatigue design, often associated with damage calculated from S-N curves. Calculation of fatigue damage from S-N curves can be affected by multiple factors, e.g. types of weld class, corrosion condition, loading conditions, stress concentration on different geometries etc. Each of them can be subject to different level of uncertainties. This study intends to recalibrate the DFFs from a detailed reliability analysis by investigating the probabilistic models derived from the database of S-N curves that has been most frequently used in offshore wind industry. The results of such study indicate that the DFFs can be reduced substantially for the corrosive environmental fatigue models from current standards to the same level of target reliability.
\end{abstract}

Keywords: fatigue; design fatigue factor; offshore wind turbine foundation; corrosion fatigue; target reliability

\section{Introduction}

Structural fatigue in the offshore wind turbine foundation is a highly uncertain and complex phenomenon. To provide conservatism, the design S-N curve is usually taken as the values associated with mean-minus-2-standard-deviaiton S-N curve, representing a $2.3 \%$ probability of exceedance [1]. Additional considerations for a safe design include the following aspects:

- Uncertainties of random loading and Miner's Rule fatigue damage calculation

- Inspection plan and the reliability of the associate inspection method

- Failure mechanism with or without corrosion protection

- Failure consequences

The DFF (Design Fatigue Factor) is introduced to be applied onto the fatigue damage calculated using the S-N curve based approach in standards such as DNVGL-RP-C203 [2], in order to provide a desired level of target reliability. Some standards use material factors to apply on stresses as an alternative to DFF, but in overall these factors enable the alignment of final design probability of failure or structural reliability to the target reliability.

Instead of calculating the failure probability of each individual design case separately, the use of DFF simplifies this process by a general level of calibration to ensure the design can achieve the target reliability. However, the generalized approach often results in over conservatism in individual cases. Since the values of DFF can constrain any fatigue related design and the foundation cost is a major component in an offshore wind farm development, it is of direct interest for an optimal design to use DFF values not to be overly conservative.

By performing a more detailed calibration of DFF through reliability analysis methods, e.g. FORM, SORM, or Monte Carlo simulation [3], based on probabilistic distribution models from test database for the frequently utilised S-N curve categories in offshore wind industry, less conservative 
DFFs can be developed which enables offshore wind farm cost reduction with the same levels of target safety.

\section{Failure Function in Reliability Analysis}

In this study, the First Order Reliability Method (FORM) has been selected to perform the reliability analysis. The detailed description of the method can be found from classic textbook such as Thoft-Christensen and Baker. [3]. For a FORM analysis, the failure function $g(Z)$ must be established in order to provide the failure curve/surface.

The failure function $g(Z)$ for a limit state can be presented as the difference of Load $(L)$ and Resistance $(R)$ modelled as stochastic processes, where the variables $Z$ are defined as probabilistic variables:

$$
g(Z)=R-L
$$

And the probability of failure $P_{f}$ is obtained by:

$$
P_{f}=P(g(Z) \leq 0)
$$

The reliability index $\beta$ is a measure of the distance from the origin to the failure surface and corresponds to the probability of failure when the limit state function is normally distributed:

$$
\beta=-\Phi^{-1}\left(P_{f}\right)
$$

The S-N curve defines the fatigue life from the allowable number of cycles $(N)$ for a given stress range ( $S$ ) by:

$$
\log N=\log K-m \log S
$$

Under different weld categories, the allowable number of cycles $N$ is governed by the $\mathrm{N}$ intercept, i.e. $\log K$ and the $S$ to the power of $-m$, i.e. the negative slope of S-N curve. The fatigue limit state function of a bilinear S-N curve, with the DFF implemented to increase the target design damage $\Delta$, can be written as:

$$
g(Z)=\Delta * D F F-\sum_{S_{i \geq \Delta s_{c}}} \frac{n_{i} t}{K_{1} S_{i}^{-m_{1}}}-\sum_{S_{i<\Delta s_{c}}} \frac{n_{i} t}{K_{2} S_{i}^{-m_{2}}}
$$

where $n_{i}$ is the number of cycles for event group $i, t$ is time; $K_{1}$ and $-m_{1}$ are the $\mathrm{N}$-intercept and the negative slope for the low-cycle part of the S-N curve, $K_{2}$ and $-m_{2}$ are the $\mathrm{N}$-intercept and the negative slope for the high-cycle part of the S-N curve, and $\Delta S_{c}$ is the stress range at the intercept of two-slope S-N curve.

As most of the fatigue S-N data are with less than $10^{6}$ to $10^{7}$ cycles, the limit state function can be further simplified following a single-slope S-N curve, and the uncertainties can be modelled as probabilistic models:

$$
g=\boldsymbol{\Delta} * D F F-(\text { Calculated Damage }=1) \times \frac{K_{1}^{C}}{\boldsymbol{X}_{\boldsymbol{K}} \boldsymbol{X}_{\boldsymbol{S}}^{-m_{1}}}
$$

where

$\Delta$ is the uncertainty induced by Miner's rule damage calculation,

$X_{K}$ is the uncertainty of S-N data representing the variation of the N-intercept in the S-N curve, i.e. $\log K$,

$K_{1} c$ is the characteristic value ofthe S-N curve, from which the fatigue damage (=1) is calculated

$X_{s}$ is the uncertainty of stress calculation and loading condition.

The effect of DFF to the reliability index $\beta$ can be demonstrated in the normalised failure space as in Figure 1. Increasing DFF shifts the failure surface away from the origin, thus increasing the reliability index $\beta$. 


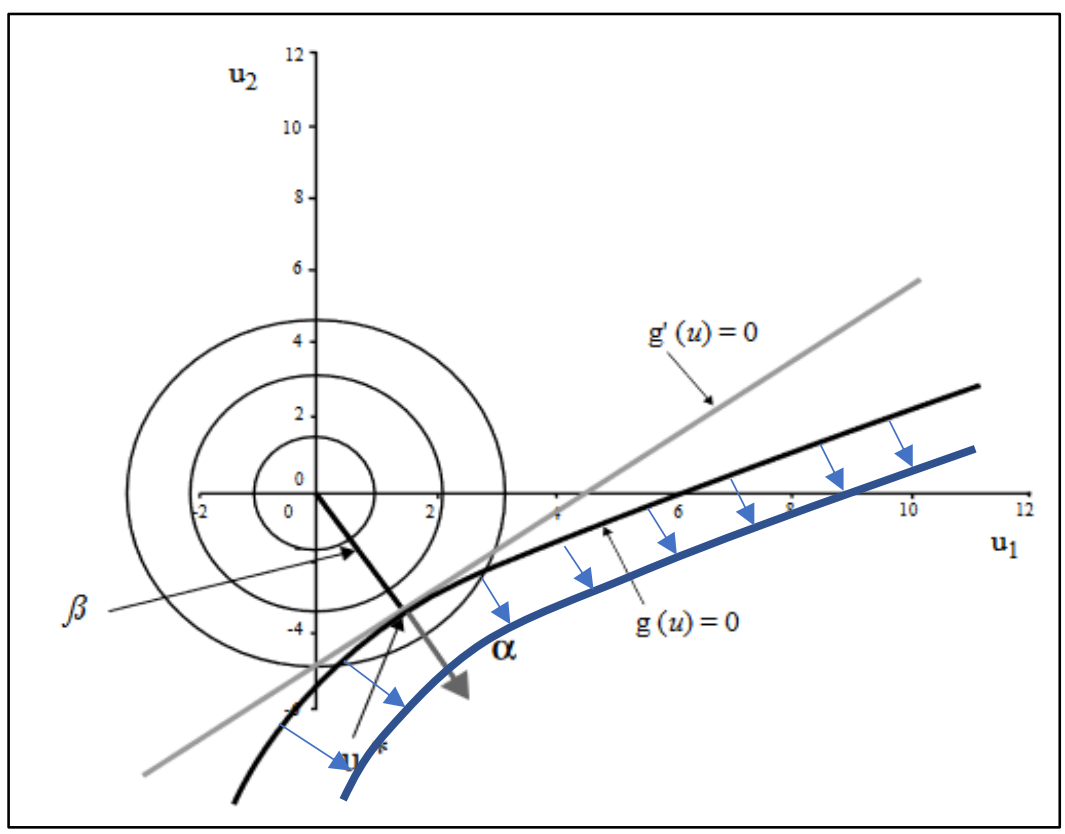

Figure 1. Effect of DFF on reliability index

\section{Uncertainty Models}

With the definition of fatigue limit state function, the uncertainties that may be encountered in the design process can be modelled as stochastic variables i,e. $\Delta, X_{K}$, and $X_{s}$ modelled as probabilistic distributions. A literature review of the uncertainty models that have been used throughout various studies is shown in subsections below. Moreover, in order to capture and quantify the uncertainty of the $\mathrm{S}-\mathrm{N}$ data, a statistical analysis is performed to derive the probabilistic models from real data.

\subsection{Uncertainty of Miner's Rule, $\Delta$}

There are a number of factors contributing to the variation of Miner's Rule such as:

- Material

- Environment (free corrosion, cathodic protected, or in-air)

- Load (random, constant, high/low frequencies)

- Interaction of the above

DNVGL-RP-C203 [2] recommended the uncertainty of Miner's rule to be modelled as a log normal distribution with mean $=1$ and $\mathrm{CoV}=0.3$. This is the most general assumption adopted in various studies ([4], [5], [6], [7], [8], [9]).

Other assumptions based on mean $=1$ but with different $\mathrm{CoV}$ s can be found as well. Such as $\mathrm{CoV}=0.1$ is assumed in [Error! Reference source not found.], and $\mathrm{CoV}=0.2$ is assumed in [10].

Zhao et al. [11] found that the CoV varies from case to case, and recommends a log normal distribution with mean $\mu=1$ and $\mathrm{CoV}=0.45$ based on averaging results from a number of tests/models, as shown in Figure 2. 


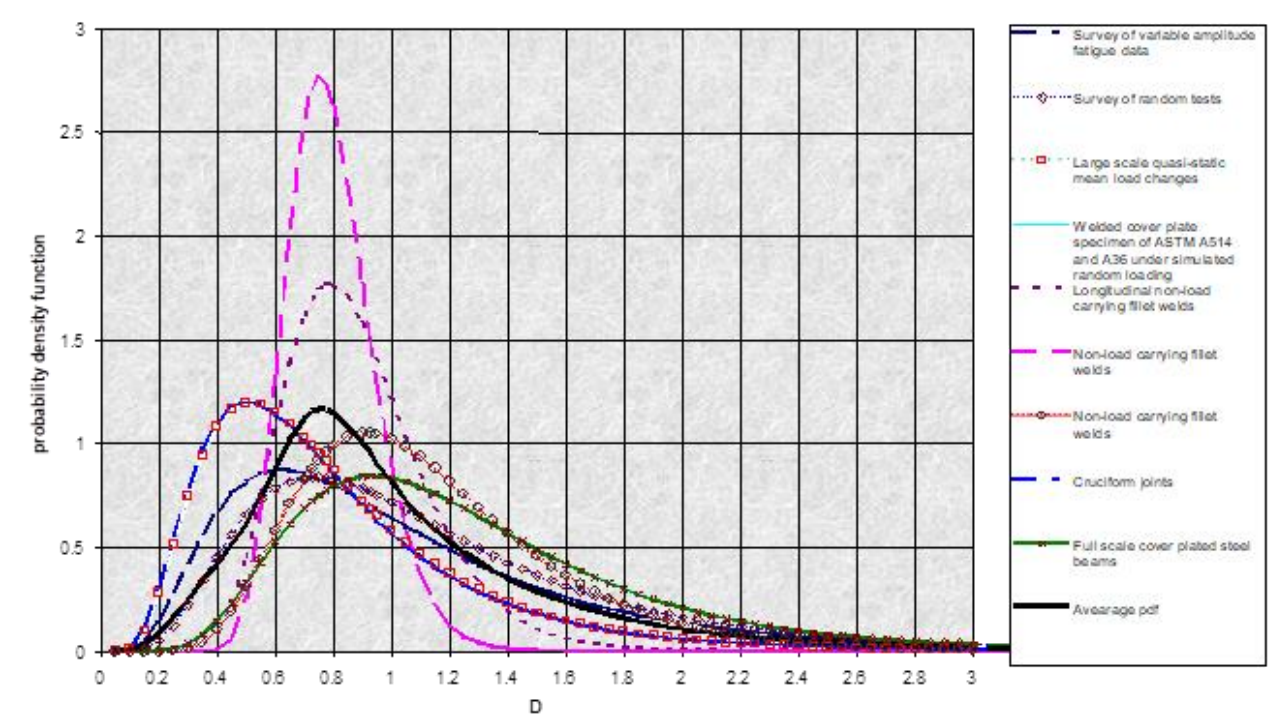

Figure 2. Probability distribution of the Miner's damage sum [11]

\subsection{Uncertainty of S-N Curve, $X_{K}$}

In order to construct a sound probabilistic model to accurately represent the uncertainties brought by different design conditions, an overview of available fatigue S-N experiment data is conducted in this study, and data analysis is performed to interpret the data to an reliable probabilistic model, i.e. $X_{K}$.

Data analysis is a very powerful tool to evaluate the fitness of current standards against the actual fatigue behaviour. As a result, a sound database with clearly defined attributes, sizable sample quantities and diverse variety of characteristics, is essential.

The database used in this study has taken input from a variety of research programme worldwide over the past half of a century in offshore oil \& gas and renewable industry. Most of the fatigue experiments are conducted in the $80 \mathrm{~s}$ and the $90 \mathrm{~s}$, where many tests have been produced in large scale programmes. There are relatively few tests conducted from the $90 \mathrm{~s}$ to now, but nevertheless included in the database.

The entries in the database have been evaluated to ensure its data integrity with the following characteristics:

- Quality of each individual test is satisfactory, i.e. certified weld procedure and weld quality

- All entries in the database are based on clearly recorded test parameters, such as:

a. Definition of loading, e.g. R-ratio, CA/VA loading, frequency

b. Material

c. Type/geometry and thickness of specimen

d. Condition of cathodic protection

e. Condition of corrosive environment

f. Fabrication details, e.g. weld profile, treatment etc.

g. Temperature

- Definition of failure criteria and the associated number of cycles

- Type of stress range, i.e. hot spot stress or nominal stress

An overview list of the S-N test data sources is listed below in Table 1.

Table 1. Source list of fatigue test database

\begin{tabular}{ccccc}
\hline Program Name & Joint Type & CP $^{1}$ Condition & Number of CA ${ }^{2}$ Test & Year \\
\hline US Highway [12] & T-joint & In-air & 71 & $1974-1993$ \\
\hline
\end{tabular}




\begin{tabular}{|c|c|c|c|c|}
\hline Program Name & Joint Type & $\mathrm{CP}^{1}$ Condition & Number of $\mathrm{CA}^{2}$ Test & Year \\
\hline Vaessen et al. [13] & T-joint & In-air/ FC ${ }^{3}$ & 75 (In-air: 42, FC: 33) & 1979 \\
\hline UKOSRP I [14] & T-joint & $\mathrm{CP} / \mathrm{FC}$ & 71 (CP: 32, FC: 39) & 1980 \\
\hline Dijkstra and de Back [15] & Tubular & $\mathrm{CP} / \mathrm{FC}$ & 4 (CP: 1, FC: 4$)$ & 1980 \\
\hline Gibstein [16] & Tubular & $\mathrm{CP}$ & 2 & 1981 \\
\hline Lourenssen et al. [17] & Tubular & FC & 2 & 1982 \\
\hline Kawasaki Steel Corp. [18] & T-joint & In-air/ FC & 32 (In-air: 16, FC: 16) & 1985 \\
\hline UKOSRP II [14] & T-Joint & In-air/ CP/ FC & 176 (In-air: 16, CP: 132, FC: 28) & 1986 \\
\hline Dover et al. [19] & Tubular & $\mathrm{CP}$ & 4 & 1986 \\
\hline University of Waterloo [20] & T-joint & $\mathrm{CP} / \mathrm{FC}$ & 30 (CP: 20, FC: 10) & 1987 \\
\hline Gerald et al. [21] & Tubular & $\mathrm{CP}$ & 2 & 1987 \\
\hline Kerr et al. [22] & Tubular & $\mathrm{CP}$ & 4 & 1987 \\
\hline Zhou et al. [23] & Tubular & $\mathrm{FC}$ & 4 & 1990 \\
\hline Ohta et al. [24] & $\begin{array}{c}\text { Transverse butt } \\
\text { welded joint }\end{array}$ & In-air & 16 & 1990 \\
\hline TWI/SINTEF [12] & Tubular & In-air/CP & 14 (In-air:8, CP: 6) & 1993 \\
\hline Nordic Program [12] & T-joint & In-air & 35 & 1993 \\
\hline HSE RPFG [1] & T-joint & In-air & 146 & 1995 \\
\hline HSE RPFG [1] & Tubular & In-air/ FC & 120 (In-air: 94, FC: 26) & 1995 \\
\hline SERC-M [25] & Tubular & In-air, FC & 5 (In-air: 1, FC: 4) & $\mathrm{N} / \mathrm{A}$ \\
\hline Lee et al. [26] & $\begin{array}{c}\text { Transverse butt } \\
\text { welded joint }\end{array}$ & In-air & 11 & 2003 \\
\hline Li et al. [27] & $\begin{array}{c}\text { Transverse butt } \\
\text { welded joint }\end{array}$ & In-air/ CP/ FC & 29 (In-air: 7, CP: 14, FC: 8) & 2006 \\
\hline Huang et al. [28] & T-joint & In-air/CP & 77 (In-air: 29, CP: 48) & 2006 \\
\hline Maddox et al. [29] & $\begin{array}{c}\text { Transverse butt } \\
\text { welded joint }\end{array}$ & In-air & 34 & 2008 \\
\hline Kim et al. [30] & $\begin{array}{c}\text { Transverse butt } \\
\text { welded joint }\end{array}$ & In-air & 34 & 2009 \\
\hline Polezhayeva et al. [31] & $\begin{array}{c}\text { Transverse butt } \\
\text { welded joint }\end{array}$ & In-air & 7 & 2009 \\
\hline FATHOMS [32] & $\begin{array}{c}\text { Transverse butt } \\
\text { welded joint }\end{array}$ & In-air/ CP & 78 (In-air: 52, CP: 17) & 2010 \\
\hline Olafsson [33] & $\begin{array}{c}\text { Transverse butt } \\
\text { welded joint }\end{array}$ & In-air/ CP & 108 (In-air: 89, CP: 19) & 2016 \\
\hline Kang [34] & $\begin{array}{c}\text { Transverse butt } \\
\text { welded joint }\end{array}$ & In-air & 54 & 2016 \\
\hline
\end{tabular}

${ }^{1}$ Cathodic Protection; ${ }^{2}$ Constant Amplitude; ${ }^{3}$ Free Corrosion

Table 2 presents the uncertainty models derived from the S-N database for different corrosion exposure category and weld class using a linear regression model. The linear regression method of the derivation can be referred to HSE report OTH 92390 [1].

Table 2. Uncertainty model of $\log K$ derived from S-N data

\begin{tabular}{ccccc}
\hline \multicolumn{2}{c}{ Weld Class / Exposure } & Distribution & Expected Value & Standard Deviation \\
\hline \multirow{4}{*}{ F curve } & In Air & & 12.604 & 0.361 \\
& CP & Normal & 12.599 & 0.416 \\
& FC & & 12.392 & 0.328 \\
\hline \multirow{3}{*}{ D curve } & In Air & & 12.679 & 0.255 \\
& CP & Normal & $*$ & $*$ \\
& FC & & $*$ & $*$ \\
\hline \multirow{3}{*}{ T curve } & In Air & \multirow{2}{*}{ Normal } & 12.915 & 0.232 \\
& CP & $*$ & $*$ \\
\hline \multicolumn{5}{r}{} \\
& FC & & $*$ &
\end{tabular}

Note that these fatigue test data has been processed with thickness correction factors proposed in DNVGL-RP-C203 [2], as in practical design exercises using size and thickness correction. 


\subsection{Uncertainty of Stress and Loading, $X s$}

The uncertainty in stress and loading can be decomposed into stress part and loading part, where the stress part can be represented by the uncertainty of Stress Concentration Factor, $X_{s c F}$, and the loading part can be represented by the uncertainty of wind and wave, $\boldsymbol{X}_{w i n d}$ and $\boldsymbol{X}_{\text {wave }}$.

$$
X_{S}=X_{\text {wind }} X_{\text {wave }} X_{S C F}
$$

\subsubsection{Wind Load Uncertainty, $\boldsymbol{X}_{\text {wind }}$}

Sørensen [37] has suggested a three-band categorisation for modelling the uncertainty of wind load depending on the accuracy and the assessment method selected for the wind measurement/analysis. The standard deviations are assumed in associate with log-normal distribution of mean $\mu=1$ for different scenarios illustrated in Table 3.

Table 3. Proposed wind load uncertainty model parameters [37]

\begin{tabular}{|c|c|c|c|}
\hline & $\begin{array}{c}\text { Band 1 } \\
\text { Standard Deviation: } 0.10 \leq \\
\sigma \leq 0.15\end{array}$ & $\begin{array}{c}\text { Band } 2 \\
\text { Standard Deviation: } \\
0.15 \leq \sigma \leq 0.20\end{array}$ & $\begin{array}{c}\text { Band } 3 \\
\text { Standard Deviation: } \\
0.20 \leq \sigma \leq 0.25\end{array}$ \\
\hline \multirow{3}{*}{$\begin{array}{c}\text { Site } \\
\text { Assessment }\end{array}$} & $\begin{array}{c}\text { More than two years of climate data, } \\
\text { corrected with Measure-correlate- } \\
\text { predict }(\mathrm{MCP}) \text { techniques }\end{array}$ & Minimum one year of climatic data & $\begin{array}{c}\text { Less than one year of data, not } \\
\text { corrected with MCP } \\
\text { techniques }\end{array}$ \\
\hline & $\begin{array}{l}\text { Wind measurement above and } \\
\text { below wind turbine hub height }\end{array}$ & $\begin{array}{l}\text { Wind measurement at hub height and } \\
\text { below }\end{array}$ & $\begin{array}{l}\text { Wind measurements below } \\
\text { hub height }\end{array}$ \\
\hline & Flat terrain with low roughness & $\begin{array}{l}\text { Non-complex site with medium } \\
\text { roughness }\end{array}$ & Complex terrain \\
\hline \multirow{3}{*}{$\begin{array}{l}\text { Dynamic } \\
\text { Response }\end{array}$} & $\begin{array}{c}\text { Structural dynamic effects through } \\
\text { model analysis, with at least } 4 \\
\text { modes considered for blade and } \\
\text { tower }\end{array}$ & $\begin{array}{l}\text { Structural dynamic effects through } \\
\text { model analysis, with at least two } \\
\text { modes considered for blade and tower }\end{array}$ & \multirow{3}{*}{$\begin{array}{l}\text { Structural dynamic effects not } \\
\text { considered }\end{array}$} \\
\hline & $\begin{array}{c}\text { Mass and stiffness properties } \\
\text { defined with FEM and validated } \\
\text { with real scale specimens }\end{array}$ & $\begin{array}{l}\text { Mass and stiffness properties defined } \\
\text { with FEM and validated with real } \\
\text { scale specimens }\end{array}$ & \\
\hline & $\begin{array}{c}\text { Eigenvalues and damping validated } \\
\text { with real scale tests }\end{array}$ & $\begin{array}{l}\text { Eigenvalues and damping not } \\
\text { validated with real scale tests }\end{array}$ & \\
\hline \multirow{5}{*}{$\begin{array}{l}\text { Aerodynamic } \\
\text { Coefficients }\end{array}$} & $\begin{array}{c}\text { Airfoil data experimentally } \\
\text { validated in wind tunnel at different } \\
\text { Re numbers } \\
\end{array}$ & $\begin{array}{l}\text { Airfoil data based on CFD, but not } \\
\text { measured in wind tunnel }\end{array}$ & $\begin{array}{c}\text { Airfoil data based on similar } \\
\text { airfoils or for a single Re } \\
\text { number } \\
\end{array}$ \\
\hline & Air foil data including 3D effects & 3D effects not included in air foil data & $\begin{array}{l}\text { 3D effect not included in } \\
\text { airfoil data }\end{array}$ \\
\hline & $\begin{array}{l}\text { Attached flow in all operating } \\
\text { regimes }\end{array}$ & Attached flow in all operating regimes & $\begin{array}{l}\text { Stall flow in relevant } \\
\text { operating regimes }\end{array}$ \\
\hline & $\begin{array}{l}\text { BEM, including Dynamic stall and } \\
\text { Tip and hub loss included }\end{array}$ & $\begin{array}{l}\text { BEM, but not including dynamic stall } \\
\text { effects nor tip and hub losses }\end{array}$ & $\begin{array}{l}\text { BEM, but not including } \\
\text { dynamic stall effects nor tip } \\
\text { and hub losses }\end{array}$ \\
\hline & Dynamic wake inflow model & Static wake inflow model & No model for wake effects \\
\hline
\end{tabular}

\subsubsection{Wave Load Uncertainty, $\boldsymbol{X}_{\text {wave }}$}

Ambuhl et al. [4] suggested to distinguish the uncertainty of wave loading by the level of assessment and the quantity of data available. A five-band rule of thumb for modelling wave load uncertainty assuming log-normal distributions with mean $\mu=1$ is suggested. The uncertainty bands and associated conditions are shown in Table 4.

Table 4. Proposed wave load uncertainty model parameters [4]

\begin{tabular}{ccc}
\hline Band & Standard Deviation & Condition \\
\hline 1 & 0.05 & $\begin{array}{c}\text { More than 2 years of wave data available and direction } \\
\text { of incoming waves considered in load calculations }\end{array}$ \\
\hline
\end{tabular}




\begin{tabular}{ccc}
\hline Band & Standard Deviation & Condition \\
\hline 2 & 0.10 & $\begin{array}{c}\text { More than 2 years of wave data available and direction } \\
\text { of incoming waves not considered in load calculations }\end{array}$ \\
\hline 3 & 0.15 & $\begin{array}{c}\text { At least 1 year of wave data available and direction of } \\
\text { incoming waves considered in load calculations }\end{array}$ \\
\hline 5 & 0.20 & $\begin{array}{c}\text { Less than 1 year of wave data available and direction } \\
\text { of incoming waves considered in load calculations }\end{array}$ \\
\hline 0.25 & $\begin{array}{c}\text { Less than 1 year of wave data available and direction } \\
\text { of incoming waves not considered in load calculations }\end{array}$ \\
\hline
\end{tabular}

\subsubsection{Stress Concentration Uncertainty, $X_{S C F}$}

In DNVGL-RP-C210 [38], a guideline has been provided for the uncertainty modelling of stress concentration in a probabilistic model. With log-normal distributions of mean $\mu=1$, five bands of standard deviation suggested based on the SCF calculation method are shown in Table 5.

Table 5. Guideline of stress concentration uncertainty model parameters by DNVGL-RP-C210 [38]

\begin{tabular}{ccc}
\hline Band & Standard Deviation & Condition \\
\hline 1 & 0.00 & $\begin{array}{c}\text { Use of FEM tools at the considered location for statistically } \\
\text { determinate systems with simple fatigue critical details }\end{array}$ \\
\hline 2 & 0.05 & $\begin{array}{c}\text { Use of FEM tools at the considered location for statistically } \\
\text { determinate systems with complex fatigue critical details }\end{array}$ \\
\hline 4 & 0.10 & $\begin{array}{c}\text { Use of FEM tools at the considered location for statistically } \\
\text { in-determinate systems with complex fatigue critical details }\end{array}$ \\
\hline 5 & 0.15 & $\begin{array}{c}\text { Use of SCF parametric equations for simple fatigue critical } \\
\text { details }\end{array}$ \\
\hline
\end{tabular}

\subsubsection{Combined Uncertainty of Environmental Loading}

To simplify the modelling of wind and wave load uncertainty, $X_{W}$ is introduced as the combination of $\boldsymbol{X}_{\text {wind }}$ and $\boldsymbol{X}_{\text {wave, }}$ i.e.

$$
X_{W}=X_{\text {wind }} \times X_{\text {wave }}
$$

In Márquez-Domínguez et al. [35], a log-normal distribution with $\mu=1$ and standard deviation $=0.25$ is suggested for OWT structure.

\section{Reliability Analysis and DFF Calibration}

With the fatigue limit state function and the probabilistic models defined, the DFFs that enable designer to reach the dedicated target reliability can be calibrated using reliability tools. FORM is a reliable numerical iteration method that solves multi-dimensional reliability problems in a very efficient way.

\subsection{DNVGL Uncertainty Model}

In order to recalibrate the DFFs for the DNVGL S-N curves, it is essential to understand the DNVGL assumption of uncertainty models. According to Section 9 in DNVGL-RP-C203 [2], and Eq. 10.4 in DNVGL-RP-C210 [38], assumptions of uncertainty model are given in Table 6 and Table 7.

Table 6. DNVGL uncertainty modelling for fatigue

\begin{tabular}{cccc}
\hline Variable & Distribution & Mean & Standard Deviation \\
\hline$\Delta$ & Log-normal & 1 & 0.3 \\
\hline$X_{K}$ & Normal & & Table 8 \\
\hline$X_{W}$ & Log-normal & 1 & 0.15 \\
\hline$X_{S C F}$ & Log-normal & 1 & 0.2 \\
\hline
\end{tabular}


Table 7. DNVGL Uncertainty Model of $X_{K}$

\begin{tabular}{|c|c|c|c|c|c|}
\hline \multicolumn{2}{|c|}{ Weld Class / Exposure } & Variable & Expected Value & Standard Deviation & Characteristic Value \\
\hline \multirow{5}{*}{ F curve } & \multirow{2}{*}{ In Air } & $\log K_{1}$ & 12.255 & 0.2 & 11.855 \\
\hline & & $\log K_{2}$ & 15.491 & 0.2 & 15.091 \\
\hline & \multirow{2}{*}{$\mathrm{CP}$} & $\log K_{1}$ & 11.855 & 0.2 & 11.455 \\
\hline & & $\log K_{2}$ & 15.491 & 0.2 & 15.091 \\
\hline & $\mathrm{FC}$ & $\log K_{1}$ & 11.778 & 0.2 & 11.378 \\
\hline \multirow{5}{*}{ D curve } & \multirow{2}{*}{ In Air } & $\log K_{1}$ & 12.564 & 0.2 & 12.164 \\
\hline & & $\log K_{2}$ & 16.006 or 16.106 & 0.2 or 0.25 & 15.606 \\
\hline & \multirow{2}{*}{$\mathrm{CP}$} & $\log K_{1}$ & 12.164 & 0.2 & 11.764 \\
\hline & & $\log K_{2}$ & 16.006 or 16.106 & 0.2 or 0.25 & 15.606 \\
\hline & FC & $\log K_{1}$ & 12.087 & 0.2 & 11.687 \\
\hline \multirow{3}{*}{ T curve } & In Air & $\log K_{1}$ & 12.88 & 0.2 & 12.48 \\
\hline & $\mathrm{CP}$ & $\log K_{1}$ & 12.58 & 0.2 & 12.18 \\
\hline & FC & $\log K_{1}$ & 12.43 & 0.2 & 12.03 \\
\hline
\end{tabular}

It can be observed from Table 8 that the probabilistic distribution of $\log K$, i.e. $X_{K}$ are based on a one-off assumption, where the design curve is always assumed to be $2 \times 0.2$ below the mean value for each of the exposure category. The DNVGL $X_{K}$ distributions are compared to the revised distributions in Table 2, which the results are shown in Figure 3 to Figure 5. It has been found that in all exposure categories available in the fatigue database, the mean strengths of the revised uncertainty models are all higher than the DNVGL models, especially for corrosive categories in F curve.

\subsection{Benchmark DNVGL Target Reliability}

By introducing the fatigue failure function (Eq. 6) with the DNVGL uncertainty models (Table 7), a benchmark target reliability can be calculated for the DFFs specified in DNVGL-ST-0126 [36], Table 4-18, i.e. $\mathrm{DFF}=3,2$, or 1 . The reliability level of $\mathrm{DFF}=3$ is found to be very close to the JCSS Model Code recommended value for moderate consequence with large cost of safety measures, which is also suggested for application of OWT substructure by Sørensen [37]. 


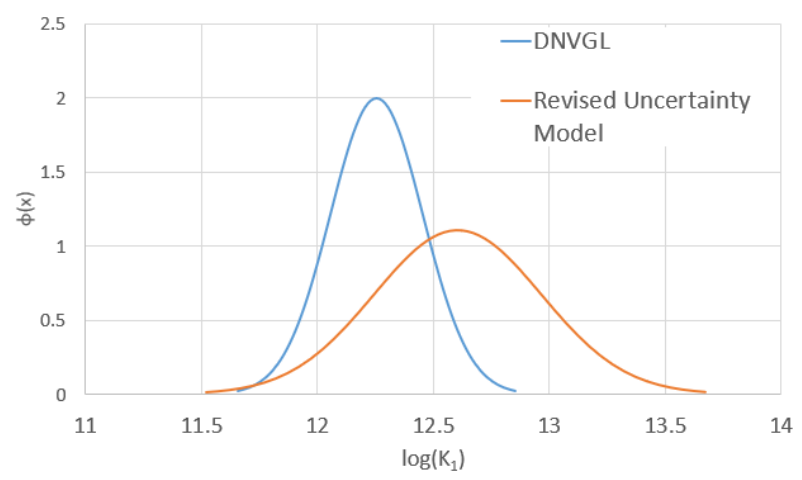

(a)

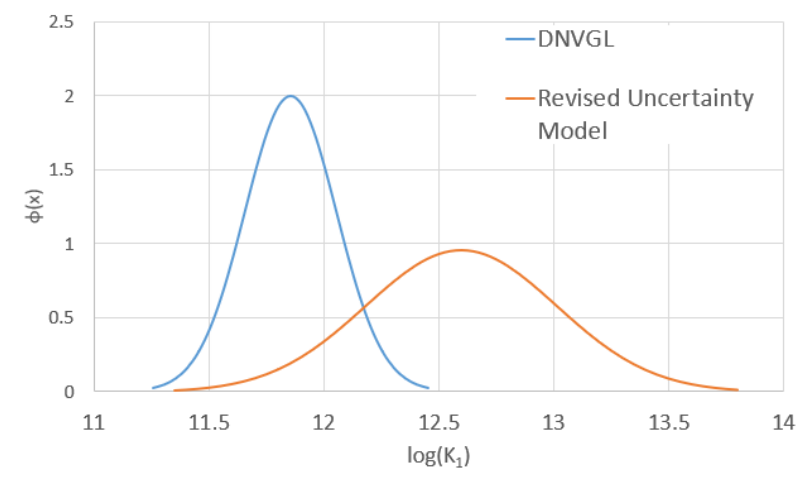

(b)

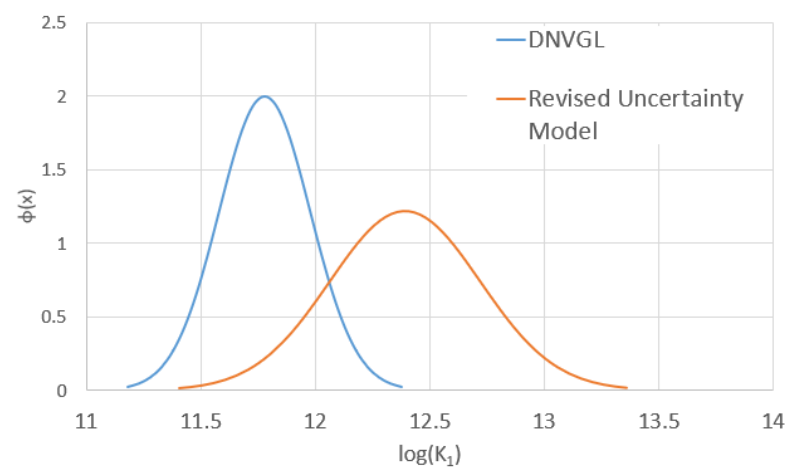

(c)

Figure 3. Comparison of XK distribution for (a) In-air F curve; (b) CP F curve; (c) FC F curve

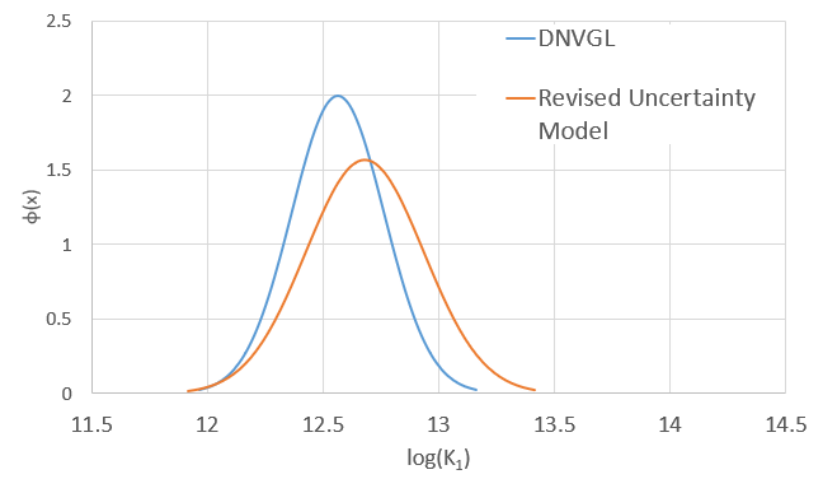

Figure 4. Comparison of $X_{K}$ distribution for In-air D curve

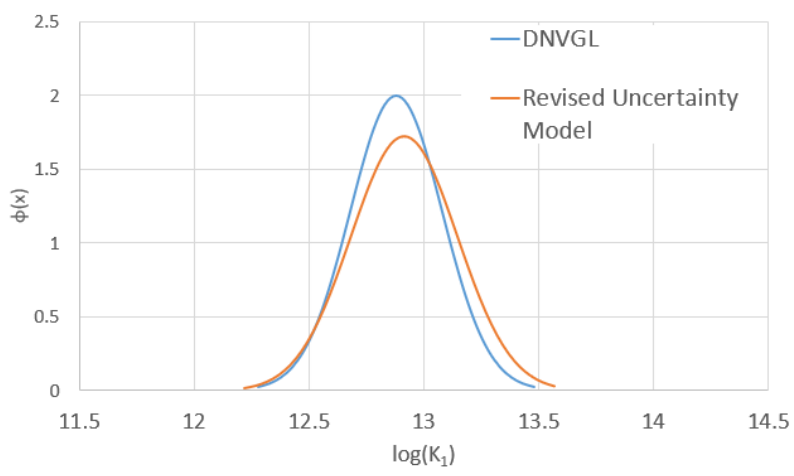

Figure 5. Comparison of $X_{K}$ distribution for In-air T curve 
Table 9. Benchmark DNVGL target reliability with $\mathrm{DFF}=3,2$, or 1

\begin{tabular}{cccc}
\hline & DFF & $\begin{array}{c}\text { Annual } \\
\text { Reliability Index }\end{array}$ & $\begin{array}{c}\text { Annual } \\
\text { Probability of } \\
\text { Failure } \boldsymbol{P}_{\boldsymbol{f}}\end{array}$ \\
\hline JCSS & - & $\boldsymbol{\Delta} \boldsymbol{\beta}$ & $5 \times 10^{-4}$ \\
\hline \multirow{2}{*}{ DNVGL } & 3.0 & 3.3 & $5.02 \times 10^{-4}$ \\
\cline { 2 - 4 } & 2.0 & 2.977 & $1.45 \times 10^{-3}$ \\
\cline { 2 - 4 } & 1.0 & 2.494 & $6.32 \times 10^{-3}$ \\
\hline
\end{tabular}

\subsection{DFF Calibration of DNVGL S-N Curve with Revised Uncertainty Model}

The DNVGL uncertainty model of $X_{K}$ is replaced by the revised uncertainty model specified in Table 2 for the DFF recalibration exercise in this study. analysis:

The DFF calibration study is based on the following assumptions, and executed with a FORM

- $\quad$ Fatigue limit state function as per Eq. 6

- Deterministic variables are defined as:
- $\quad \mathrm{K}_{1} \mathrm{c}$ as per DNVGL-RP-C203 [2], listed as the characteristic values in Table 7
- $\mathrm{m}_{1}=3$, for single slope $\mathrm{S}-\mathrm{N}$ curve
- $\mathrm{DFF}=0$ to 10

- Stochastic variables are defined as per DNVGL, i.e. Table 6, except $X_{K}$ is revised

The benefit of revised uncertainty model $X_{K}$ using the fatigue test database can be quantified by the change of required DFF to reach the same target reliability level.

According to Figure 6 to Figure 10, same level of DNVGL benchmark target reliability can be achieved using a similar or lower DFF value.

It can be seen that all three environmental conditions (In-air, CP, FC) are showing lower DFF for the same benchmarked reliability level for $\mathrm{F}$ curve. This is mainly because of the higher mean strength derived from data. The In-air D curve requires slightly lower DFF comparing to DNVGL specification, and the In-air T curve gives approximately the same DFF values comparing to DNVGL specification.

Therefore, the recommended practice given by DNVGL, of which the minimum DFFs are either 3,2 , or 1 depending on the exposure category and accessibility for inspection and repair, is revisited in Table 8.

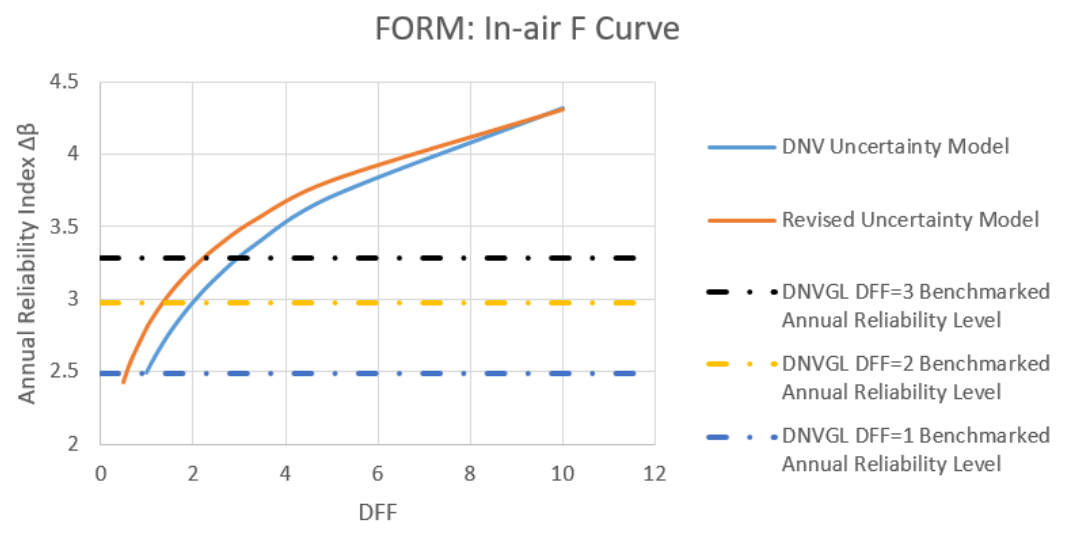

Figure 6. Calibration of DFF for DNVGL In-air F curve 


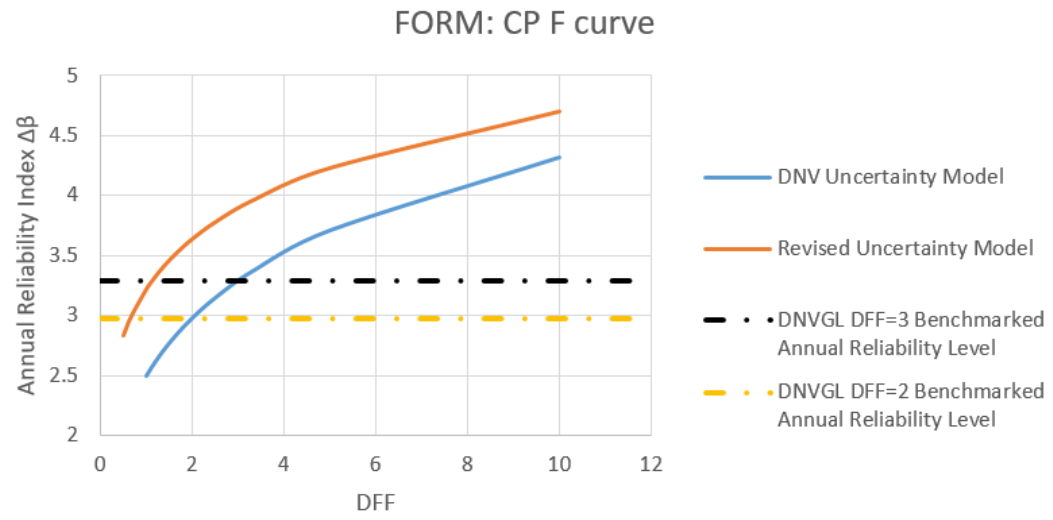

Figure 7. Calibration of DFF for DNVGL CP F curve

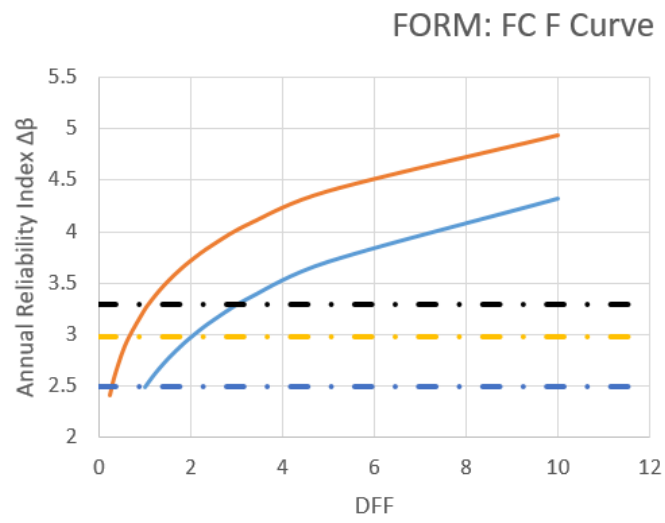

- DNV Uncertainty Model

Revised Uncertainty Mode

- • DNVGL DFF=3 Benchmarked Annual Reliability Level

- . DNVGL DFF=2 Benchmarked Annual Reliability Level

- - DNVGL DFF=1 Benchmarked Annual Reliability Level

Figure 8. Calibration of DFF for DNVGL FC F curve

FORM: In-air D Curve

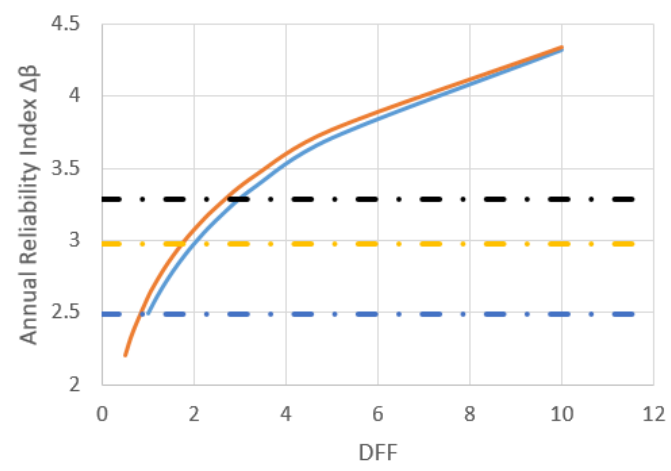

- DNV Uncertainty Model

Revised Uncertainty Model

- • DNVGL DFF=3 Benchmarked Annual Reliability Level

- DNVGL DFF=2 Benchmarked Annual Reliability Level

- . DNVGL DFF=1 Benchmarked Annual Reliability Level

Figure 9. Calibration of DFF for DNVGL In-air D curve 


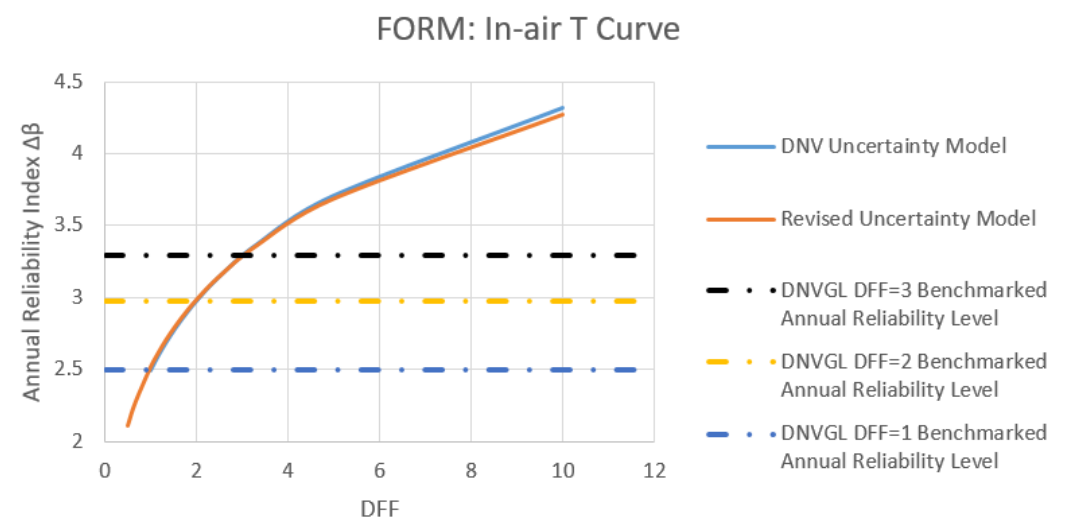

Figure 10. Calibration of DFF for DNVGL In-air T curve

Table 8. Revised DFF for DNVGL Design S-N Curves

\begin{tabular}{|c|c|c|c|c|c|c|c|c|c|}
\hline \multirow[b]{2}{*}{ Location } & \multirow{2}{*}{$\begin{array}{l}\text { Accessibility } \\
\text { for } \\
\text { inspection } \\
\text { and repair }\end{array}$} & \multirow[b]{2}{*}{$\begin{array}{c}\text { S-N } \\
\text { curve }\end{array}$} & \multirow{2}{*}{$\begin{array}{l}\text { Minimum } \\
\text { DFF } \\
\text { (DNVGL) }\end{array}$} & \multirow{2}{*}{$\begin{array}{c}\text { Benchmarked } \\
\text { Annual } \\
\text { Probability } \\
\text { of Failure }\end{array}$} & \multicolumn{5}{|c|}{$\begin{array}{c}\text { Minimum DFF (Updated Reliability } \\
\text { Model) }\end{array}$} \\
\hline & & & & & $\begin{array}{l}\text { In-air } F \\
\text { curve }\end{array}$ & $\begin{array}{l}\text { CP F } \\
\text { curve }\end{array}$ & $\begin{array}{l}\text { FC F } \\
\text { curve }\end{array}$ & $\begin{array}{c}\text { In-air } \\
\text { D } \\
\text { curve }\end{array}$ & $\begin{array}{l}\text { In-air } \\
\mathrm{T} \\
\text { curve }\end{array}$ \\
\hline Atmospheric & $\mathrm{No}$ & In-air & 3 & $5.02 \times 10^{-4}$ & 2.26 & - & 1.09 & 2.67 & 3.00 \\
\hline Zone & Yes & / FC & 1 & $6.32 \times 10^{-3}$ & 0.58 & - & 0.29 & 0.81 & 0.96 \\
\hline $\begin{array}{l}\text { Upper splash } \\
\text { zone (above }\end{array}$ & No & In-air & 3 & $5.02 \times 10^{-4}$ & 2.26 & - & 1.09 & 2.67 & 3.00 \\
\hline MWL) & Yes & & 2 & $1.45 \times 10^{-3}$ & 1.34 & - & 0.65 & 1.73 & 1.96 \\
\hline $\begin{array}{l}\text { Lower splash } \\
\text { zone (below }\end{array}$ & No & $\mathrm{CP} /$ & 3 & $5.02 \times 10^{-4}$ & - & 1.12 & 1.09 & - & - \\
\hline MWL) & Yes & & 2 & $1.45 \times 10^{-3}$ & - & 0.65 & 0.65 & - & - \\
\hline Submerged & No & & 3 & $5.02 \times 10^{-4}$ & - & 1.12 & 1.09 & - & - \\
\hline zone & Yes & $\begin{array}{c}\mathrm{CP} / \\
\mathrm{FC}\end{array}$ & 2 & $1.45 \times 10^{-3}$ & - & 0.65 & 0.65 & - & - \\
\hline Scour zone & No & & 3 & $5.02 \times 10^{-4}$ & - & 1.12 & 1.09 & - & - \\
\hline $\begin{array}{c}\text { Below scour } \\
\text { zone }\end{array}$ & No & $\begin{array}{l}\mathrm{CP} / \\
\mathrm{FC}\end{array}$ & 3 & $5.02 \times 10^{-4}$ & - & 1.12 & 1.09 & - & - \\
\hline
\end{tabular}

\section{Discussion and Conclusions}

DFFs have been used in fatigue design of offshore wind turbine foundation to ensure a desirable level of safety without elaborate probabilistic analysis. However, it has been found that the DFFs in current standards are overly conservative especially for special cases such as fatigue with or without corrosion protection in sea water.

For the purpose of reducing the conservatism, reliability analysis and subsequent recalibration of DFFs have been conducted using probabilistic models based on an extensive fatigue test database.

This recalibration of DFFs has shown that the revised DFFs can be substantially lower than those used in current design standards, especially in corrosive environment.

It is therefore proposed to revise the DFFs for D, F, and T S-N weld/joint class, especially for corrosion conditions with or without cathodic protection to reduce over conservatism in the fatigue evaluation while still providing the same target reliability of OWT substructures as in the standards.

The DFFs could be further improved by

1) further study, to refine the fatigue strength model to reduce model uncertainty in the fatigue analysis.

2) to expand the test database to consider other weld/joint categories that are not investigated in this study due to lack of data, with additional test programs. 


\section{Acknowledgments:}

This study was funded by the Bureau of Ocean Energy Management (BOEM), U.S. Department of the Interior, Washington, D.C., under Contract 140M0119C0010, with the exception of the fatigue test database, which was developed by ODE.

\section{References}

1. OTH 92 390, 1999. Background to New Fatigue Guidance for Steel Joints and Connections in Offshore Structures.

2. DNVGL-RP-C203, Jan 2020. Fatigue Design of Offshore Steel Structures

3. Thoft-Christensen, P. and Baker, M. J., 'Structural Reliability Theory and Its Applications,' SpringerVerlag, New York, 1982.

4. Ambühl, S.; Ferri, F.; Kofoed J.P.; Sørensen, J. Fatigue Reliability and Calibration of Fatigue Design Factors of Wave Energy Converters, International Journal of Marine Energy, Vol. 10, Jun 2015; pp. 17-38. DOI.org (Crossref), doi: 10.1016/j.ijome.2015.01.004

5. Dong, W.; Moan, T.; Gao, Z. Fatigue reliability analysis of the jacket support structure for offshore wind turbine considering the effect of corrosion and inspection, Reliability Engineering \& System Safety, Vol. 106, Oct 2012; pp. 11-27. DOI.org (Crossref), doi: 10.1016/j.ress.2012.06.011

6. Steenbergen, R.; van Gelder, P.; Miraglia, A.; Vrouwenvelder, A. Safety, Reliability and Risk Analysis: Beyond the Horizon. CRC Press, 2013.

7. Horn, J.; Leira, B. Fatigue reliability assessment of offshore wind turbines with stochastic availability, Reliability Engineering \& System Safety, Vol. 191, Nov 2019, 106550. DOI.org (Crossref), doi: 10.1016/j.ress.2019.106550

8. SSC-392, 1996. Probability Based Ship Design: Implementation of Design Guidelines

9. Velarde, J.; Kramhøft, C.; Mankar, A.; Sørensen, J. Uncertainty Modeling and Fatigue Reliability Assessment of Offshore Wind Turbine Concrete Structures, International Journal of Offshore and Polar Engineering, Vol. 29, Issue 02, June 2019, pp. 165-171. DOI.org (Crossref), doi: 10.17736/ijope.2019.i154

10. Rafsanjani, H.; Sørensen, J. Reliability Analysis of Fatigue Failure of Cast Components for Wind Turbines, Energies, Vol. 8, No. 4, 2015, pp. 2908-23. DOI.org (Crossref), doi: 10.3390/en8042908

11. Zhao, W.; Stacey, A.; Prakash, P. Probabilistic Models of Uncertainties in Fatigue and Fracture Reliability Analysis, 21 $1^{\text {st }}$ International Conference on Offshore Mechanics and Arctic Engineering, Vol 3, Jan 2002. DOI.org (Crossref), doi: 10.1115/OMAE2002-28611

12. OTO 99 058, 2000. Fatigue Design Curves for Welded Joints in Air \& Seawater Under Variable Amplitude Loading.

13. Vaessen, G.; de Back, J.; van Leeuwen, J. Fatigue Behavior of Welded Steel Joints in Air and Seawater. Journal of Petroleum Technology, 34(02), 1982; pp. 440-446. DOI.org (Crossref), doi:10.2118/8621-PA

14. OTH 92 392, 1994. A Survey of Some Recent Corrosion Fatigue Tests on Welded Joints in Steel Plate

15. Dijkstra, O. D.; de Back, J. Fatigue Strength of Tubular T- And X-Joints. Offshore Technology Conference, Offshore Technology Conference, 1980. DOI.org (Crossref), doi:10.4043/3696-MS.

16. Gibstein, M. B. Fatigue strength of welded tubular joints tested at Det norske Veritas laboratories. Proceedings of the Conference on Steel in Marine Structures, Paper No 8.4, Paris, 1981.

17. Lourenssen, A. A.; Dijkstra, O. D. Fatigue Tests on Large Post Weld Heat Treated and As Welded Tubular T-Joints. Offshore Technology Conference, Offshore Technology Conference, 1982. DOI.org (Crossref), doi:10.4043/4405-MS.

18. Narumoto, A.; Akahide, K.; Kikukawa, S.; Kawai, Y.; Hashimoto, O. Corrosion Fatigue Strength of HighStrength Low Alloy Steels for Offshore Structures. Offshore Technology Conference, Offshore Technology Conference, 1985. DOI.org (Crossref), doi:10.4043/5003-MS.

19. Dover W. D.; Wilson T. J. Corrosion fatigue of tubular welded joints. Advances in Fracture Research, Proceedings of the Sixth International Conference on Fracture, ICF6, S.R. Valluri et al (ed.), New Delhi, December 1984, Pergamon Press, pp. 2505-2512. 
20. Vosikovosky O.; Bell, R.; Burns, D. J.; Monaupt U. H. Effects of Cathodic Protection and Thickness on Corrosion Fatigue Life of Welded Plate T-Joints. Papers Presented at the Conference on Steels in Marine Structures, Delft, Holland, 1987.

21. Gerald, J.; Bignonnet, A.; Lieurade, H. P.; Lecoq, H. Corrosion fatigue tests on high strength steel tubular $X$ nodes with improved welds. Steel in Marine Structures, Proceedings of the third International ECSC Offshore Conference on Steel in Marine Structures (SIMS ‘87), Delft, The Netherlands, June 1987, Elsevier Science Publishers, pp. 455-463.

22. Kerr, J.; Holmes. R.; Brown G. M. Fatigue of large tubular joints subjected to cathodic protection. Steel in Marine Structures, Proceedings of the third International ECSC Offshore Conference on Steel in Marine Structures (SIMS '87), Delft, The Netherlands, June 1987, Elsevier Science Publishers, pp. 479-487.

23. Zhou, M.; Yao, M.; Shi, L. Improvement of Fatigue strength of tubular T joint in offshore platforms due to postweld treatment. China Ocean Engineering, China Ocean Press, Vol.4, No.2, 1990, pp. 189-198.

24. Ohta, A.; Mawari, T.; Suzuki N. Evaluation of effect of plate thickness on fatigue strength of butt welded joints by a test maintaining maximum stress at yield strength. Engineering Fracture Mechanics, Vol.37, Issue 5, 1990; pp. 987-993. DOI.org (Crossref), doi: 10.1016/0013-7944(90)90022-9.

25. Raghava, G. Corrosion Fatigue Behaviour of Cathodically Protected Stiffened Steel Tubular T Joints. PhD thesis, Anna University, Chennai, 1998.

26. Lee. JK.; Yoon, TY.; Chang, SP. The Fatigue Performance of Buttwelded Joint with thick Plates. Research Institute of Industrial Science and Technology, RIST 17(3), 2003, pp. 249-255.

27. Li. Y.; Hou. B. Corrosion Fatigue of Welded Joints of Steel for Marine Platform. Indian Journal of Engineering and Material Sciences, Vol.13, Issue 5, 2006, pp. 467-470.

28. Huang. X.; Wang, Z. Durability method on corrosion fatigue performance of AH 32 steel. Frattura ed Integrità Strutturale, Vol. 13, No. 48, 2019, pp.481-490. DOI.org (Crossref), doi: 10.3221/IGF-ESIS.48.46

29. Maddox. S.J.; Zhang. Y. Comparison of Fatigue of Girth-welds in Full-scale Pipes and Small-scale Strip Specimens. Proceedings of the $27^{\text {th }}$ International Conference on Offshore Mechanics and Arctic Engineering, Estoril, Portugal, 2008. DOI.org (Crossref), doi: 10.1115/OMAE2008-57103

30. Kim. KN.; Lee, SH.; Jung. KS. Evaluation of factors affecting the fatigue behaviour of butt welded joints using SM520C-TMC steel. International Journal of Steel Structure, Vol. 9, Issue 3, 2009, pp. 185-193. DOI.org (Crossref), doi: 10.1007/BF03249493

31. Polezhayeva, H.; Badger, C. Effect of plate thickness on fatigue strength of base material and butt welded specimens made from EH40 steel thick plates: Phase 1. Proceedings of the Nineteenth International Offshore and Polar Engineering Conference (ISOPE), Osaka, Japan, 2009, pp. 366-373.

32. EUR 24214, 2010. Fatigue behaviour of high-strength steel-welded joints in offshore and marine systems.

33. Olafsson, O. M. Improved Design Basis of Welded Joints in Seawater. PhD thesis, Technical University of Denmark, Lyngby, 2016.

34. Kang. SK. Thickness Effect of Fatigue on butt weld joints. TSCF 2016 Shipbuilders Meeting, Korean Register, Korea, 2016.

35. Márquez-Domínguez, S.; Sørensen, J. Fatigue Reliability and Calibration of Fatigue Design Factors for Offshore Wind Turbines, Energies, Vol. 5, No. 6, 2012, pp. 1816-34.

36. DNVGL-ST-0126, Jul 2018. Support structures for wind turbines

37. Sørensen, J. Reliability Assessment of Wind Turbines. $12^{\text {th }}$ International Conference on Applications of Statistics and Probability in Civil Engineering, Vancouver, CA, July 12-15, 2015. DOI.org (Crossref), doi:10.14288/1.0076166

38. DNVGL-RP-C210, Nov 2015. Probabilistic Methods for Planning of Inspection for Fatigue Cracks in Offshore Structures 